\title{
Hydrogeological researches in the 4D cartography program in the coastal zone of the southern Baltic
}

\author{
Mirosław Lidzbarski ${ }^{1}$, Ewa Tarnawska ${ }^{1}$ \\ ${ }^{1}$ Marine Branch of Polish Geological Insitute - NRI, 5 Kościerska str., 80-328 Gdańsk
}

\begin{abstract}
The aim of the pilot programme of the 4D cartography in the coastal zone of the southern Baltic is to develop appropriate forecasts concerning the southern Baltic coastline alterations with reference to the geological structure of the coast and anticipated changes of climate. The effects of these changes on the infrastructure, aquatic plant habitats as well as major fresh water reservoirs responsible for water supply for both municipal and industrial purposes will also be thoroughly analysed.
\end{abstract}

The project is executed as part of the tasks of the Polish Geological Survey, aiming to monitor and recognize potential geological and hydrogeological hazards (Kramarska at al., 2014).

\section{GOALS OF THE PROJECT}

The basis for the development of the programme is the geological and hydrological research conducted on the pilot section of the seashore between Władysławowo and Lubiatowo. More meticulous research was carried out in the vicinity of Jastrzębia Góra, where the coastal erosion in the active part of the cliff coast is increased and the conservation activities do not seem to produce the expected outcome. The research, which has been conducted since July, 2012, aims to create accurate spatial geological-morphometric models of the coastline at a specific time record (4D). It is also essential that the hydrogeological conditions affecting the erosion of the coastline should be recognized. Groundwater circulation systems have been identified and the correlation between the pace of the geodynamic changes occurring on the cliff coast and the geological structure and hydrogeological conditions has been established.

Erosive processes occurring on the seashore are shaped not only by outer factors, but also by inner ones. The abrasion of cliff coast seems to be particularly dangerous as the occurrence of landslides is affected by hydrogeological conditions, land-use planning as well as human pressure.

\section{INVESTIGATION AREA}

Conservation measures which are supposed to prevent, or at least reduce, the adverse phenomena have been taken on selected sections of the cliff coast. The planning of remedial and maintenance work appears difficult and is highly vulnerable due to the lack of reliable data concerning the occurrence of the groundwater circulation system in the area of the cliff.

\section{METHODS AND RANGE OF RESEARCH}

As part of fieldwork, detailed hydrogeological and hydrochemical mapping was conducted. Within the research area, all occurrences of groundwater and surface water, particularly salt waters, were documented. The preliminary assessment of the origin and chemical composition of groundwater and surface waters from springs was also carried out. The 


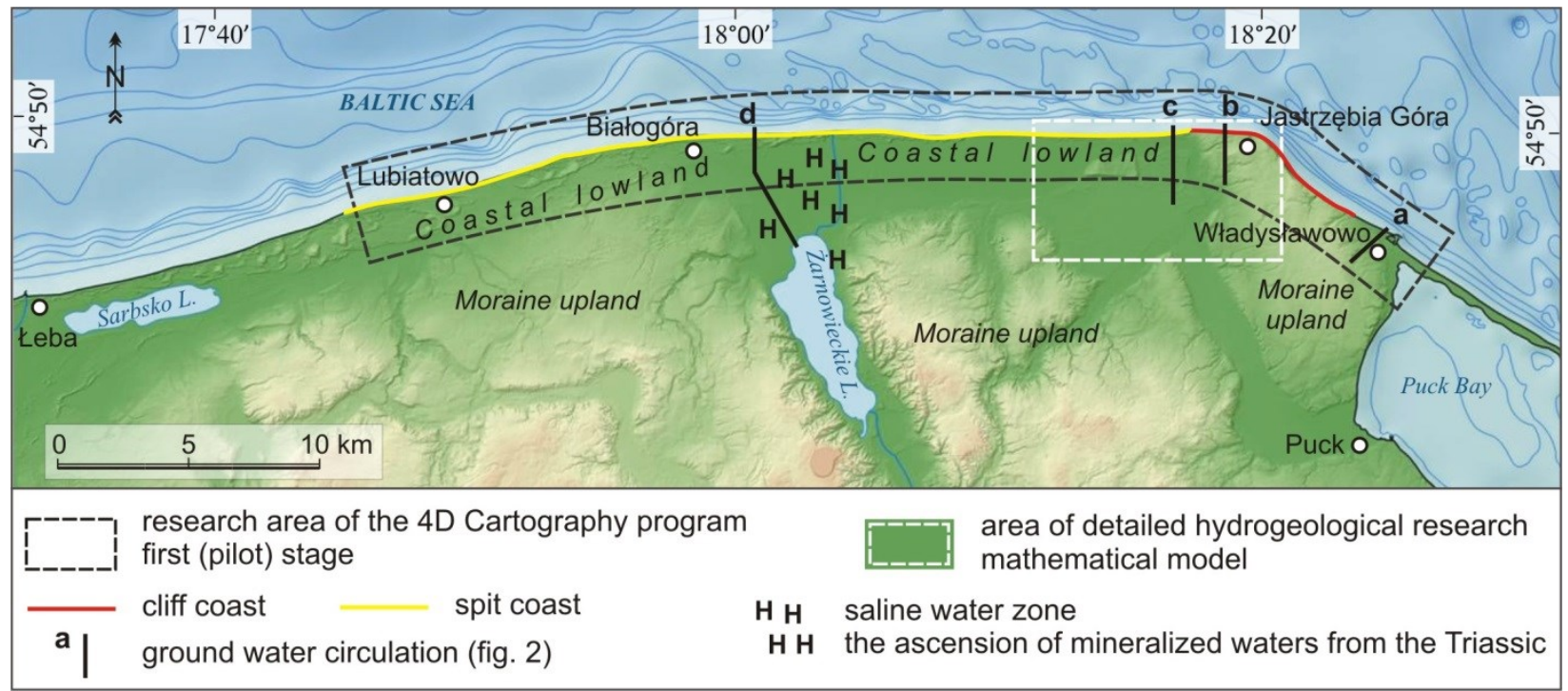

Figure 1. Investigation area along the Baltic coast in Gdańsk Region. Cross-sections are given on fig. 2 .

obtained information along with the hydrogeological archive data and the results of geological research have provided the basis for the creation of a three-dimensional mathematical model of hydrogeological processes. The internal structure, boundaries as well as spatial geometry of the aquifer were determined along with its full hydrogeological description. The groundwater dynamics, the intensity of horizontal and vertical flows, as well as salt water and brackish water zones were also recognized.

Geophysical methods and shallow drilling (probing) both in the cross-border land or sea area were applied. The terrestrial laser scanner was used to register all the changes in the morphology of the seashore (Kamiński at al., 2012).

\section{HYDROGEOLOGICAL MODEL}

For the purpose of numerical modelling of hydrogeological processes, the programme ModFlow version 2000 from the software package GMS 8.3 has been used. The research area of $7.2 \mathrm{~km}^{2}$ has been digitized by means of the square grid $10 \times 10 \mathrm{~m}$ (fig. 3). The total number of computational blocks amounted to 408480. On the basis of the adopted conceptual model, the system of aquifers occurring in the area of research has been subjected to certain schematization. During the process of aquifer aggregation, the directions of groundwater flows as well as piesometric pressure differences were taken into consideration. As a result four model layers have been distinguished. The identification of directions of groundwater flows and the groundwater flow balance have been conducted in three basic variants simulating different levels of underground water consumption:

Variant 1 - the current state of groundwater abstraction,

Variant 2 - the lack water intakes exploitation, displaying the restoration of natural piesometric surface in the area of research;

Variant 3 - the simulation of hydrogeological conditions, taking into consideration the projected climate changes (rise in the sea level - drainage base by 1 metre).

The hydrogeological conditions of the coastal zone include two aquifer levels: the Quaternary level and the Neogene and Palaeogene level, which remain in a close hydraulic connection with each other. The coastal highlands also include intermoraine aquifer levels, 
and in the area of the coastal lowland the Pleistocene and Holocene aquifer connected with fluvioglacial, aeolian and marine sediments can be found. In the sandbars fresh groundwater commonly occurs in the dune sands.

The groundwater recharge occurs as a result of rainwater infiltration. The groundwater flow in the direction of the Baltic Sea predominates in the horizontal flows. Local groundwater circulations of limited range are generated within the coastal dune zone as well as in first subsurface aquifers, from which groundwater flows towards the seashore, local watercourses and drainage ditches. The system of perched water circulation occurring in the vadose zone is more complex. In the immediate surroundings of the active part of the cliff coastline in Jastrzębia Góra four levels of perched water have been identified.

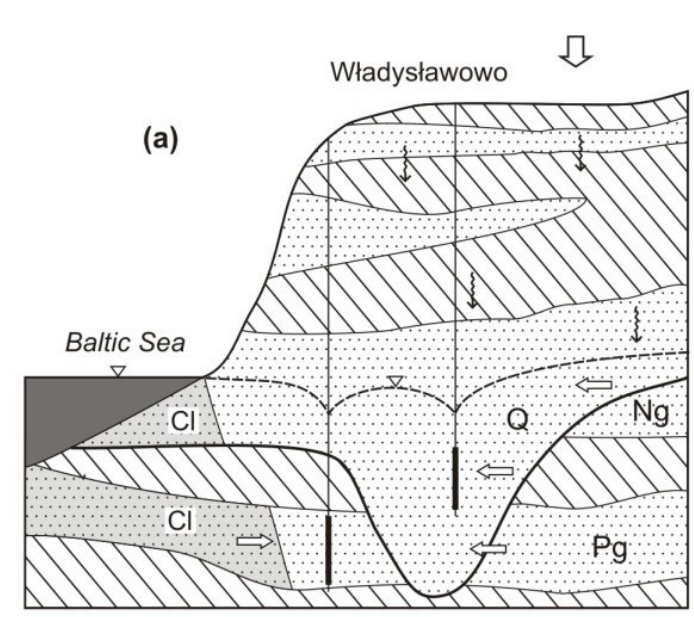

(c)

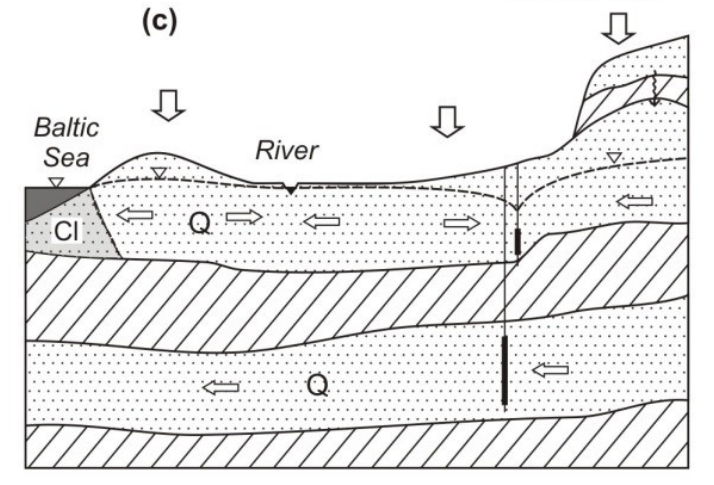

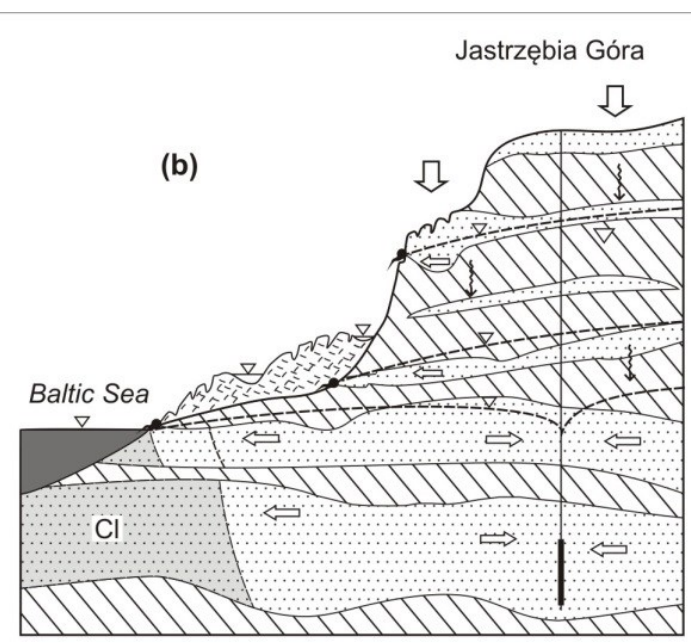

(d)

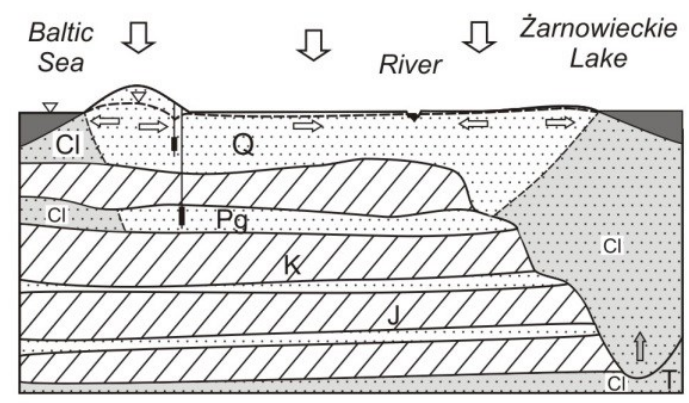

\begin{tabular}{|c|c|c|c|}
\hline & aquifer: sands, gravels & --므-- & groundwater table \\
\hline & aquitard: tills, muds, clays & $\hookleftarrow$ & groundwater fow direction \\
\hline $\mathrm{Cl}$ & salt or brackish water & $\xi$ & percolation \\
\hline$\because \because \because$ & colluvium of land slide & 凡 & recharge by rainfalls (infiltration) \\
\hline 亿 & ascension & م & spring \\
\hline
\end{tabular}

$\begin{array}{lll}\begin{array}{c}\text { screened } \\ \text { wells }\end{array} & \mathrm{Q} & \text { Quaternary } \\ & \mathrm{Ng} & \text { Neogene } \\ & \mathrm{Pg} & \text { Paleogene } \\ \mathrm{K} & \text { Cretaceous } \\ \mathrm{J} & \text { Jurassic } \\ & \mathrm{T} & \text { Triassic }\end{array}$

Figure 2. Different groundwater circulation systems along the investigated coasts. 


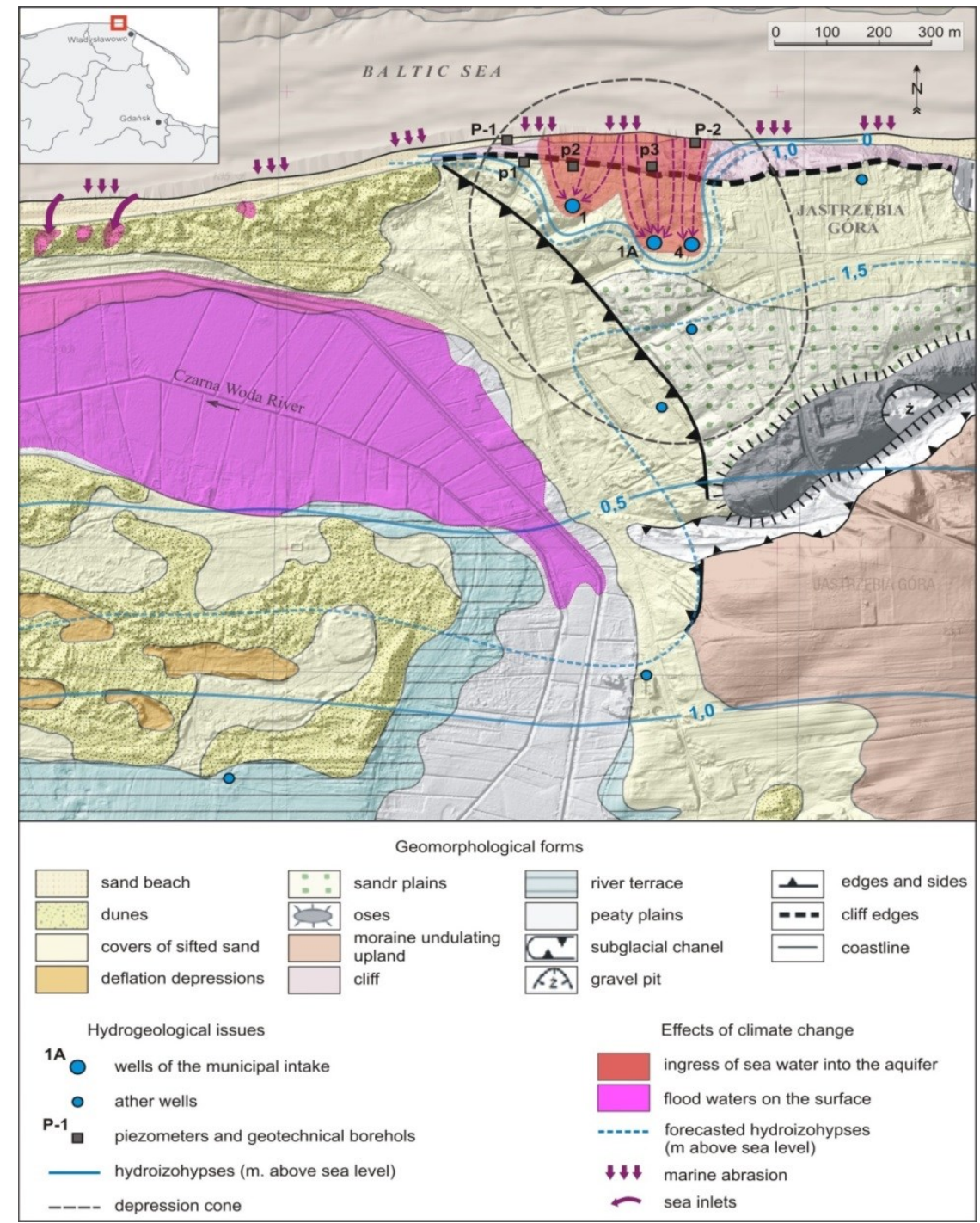

Figure 1. Predicted effects of climate change in the coastal zone based on model tests.

In the coastal zone of the Baltic Sea in question two base drainage zones have been recognized - the offshore zone in the cliff section and the coastline zone in the dune section of the shore. In Jastrzębia Góra and other areas of excessive consumption of groundwater, the offshore drainage through poorly permeable seabed sediments is reduced, and in the case of excessive exploitation can even become temporarily reversed, which in turn contributes to marine waters ingression (Prussak, 1987). To the north of Żarnowiec Lake the groundwater flow extends to the Triassic layers, where chloride concentrations exceed $11 \mathrm{~g} / \mathrm{dm}^{3}$.

The results of flow modelling allowed for the analysis of hydrodynamic alterations coming from the projected climatic changes. The computational simulation was based on an extreme variant which assumes the rise of the Baltic Sea level by 1 metre. The scenario analysing the change of hydrodynamic conditions with such a high drainage base demonstrated farreaching changes in the hydrographic system as well as in the system of groundwater circulation. The total quantity of groundwater participating in the circulation will decrease by approximately $15 \%$. The flow rate of water draining away to the Baltic Sea will increase at the expense of the drainage through surface water (Lidzbarski, Tarnawska, 2015). 
More extensive impacts of groundwater at the foot of the cliff as well as in the colluvia zone by approximately $10 \%$ should also be expected. As a result of the rise in the drainage base, the geotechnical conditions of the soil at the foot of the cliff will become weakened. They will become more prone to potential landslides. Damming up of the marine waters which frequently occurs in this area will also contribute to the loss of stability of cliff slopes. As a result of the hydrodynamic changes, the seashore will be more susceptible to abrasion, not only in the cliff zone, but on the sandbar stretches of the seacoast as well. In the coastal zone, the terrain surface will be flooded by groundwater and seawater, which will in effect create considerable lagoon-like pools. Furthermore, as a result of marine water intrusion, groundwater in the coastal zone will be affected with significant salinity. In the vicinity of Żarnowiec Lake, the zone of ascending water will blend with saline water as a result of marine water intrusion.

\section{CONCLUSIONS}

Groundwaters occurring in the coastal zone have a detrimental effect on the stability of the Cliff coast. They weaken the strength properties of cohesive soil. The hydrodynamic change forecast has been formulated by means of the three-dimensional model of hydrogeological conditions of the coastal aquifer system. Taking into consideration the possible scenario of climatic changes, it is predicted that the abrasion threat to the seashore will rise in the cliff coast zone. The sandbar coastline will be exposed to destructive processes from two sides: the increased abrasion from the sea and the flooding of coastal plains from the land. The information obtained during the research work will be helpful in forecasting mass wasting (geohazards) within the area of the Cliff coast.

\section{LITERATURE}

KAMIŃSKI M., KRAWCZYK M., ZIENTARA P., 2012 - Recognition of geological structures of Jastrzębia Góra cliff by geoelectrical imaging method for landslide geohazards estimation. [in polish, eng. sum]. PGI-NRI Biul., vol. 452: 119-130.

LIDZBARSKI M., TARNAWSKA E., 2015 - Hydrogeological investigations of the cliff seashore for geohazards estimation and forecast. [in polish, eng. sum]. Przegl. Geol., vol. 63, nr 10.

KRAMARSKA R., UŚCINOWICZ G., JURYS L., JEGLIŃSKI W., PRZEŹDZIECKI P., FRYDEL J., TARNAWSKA E., LIDZBARSKI M., DAMRAT M., WOŹNIAK M., 2014 Pilot project of 4D mapping on the seashore of southern Baltic. [in polish]. Unpublished. Arch. Of PGI-NRI. Marine Branch. Gdańsk.

PRUSSAK W., 1987 - Hydrogeological documentation of groundwater resources of Quaternary-Tertiary aquifer. [in polish]. Unpublished. POLGEOL Com. Warsaw. 